\title{
The Developmental Switch in GABA Polarity Is Delayed in Fragile X Mice
}

\author{
Qionger He, ${ }^{1}$ Toshihiro Nomura, ${ }^{1,2}$ Jian $\mathrm{Xu},{ }^{1}$ and Anis Contractor ${ }^{1,3}$ \\ ${ }^{1}$ Department of Physiology, Feinberg School of Medicine, Northwestern University, Chicago, Illinois 60611, ${ }^{2}$ Department of Pediatrics and Department of \\ Physiology, School of Medicine, Keio University, Shinjuku-ku, Tokyo 160-8582, and ${ }^{3}$ Department of Neurobiology, Weinberg College of Arts and Sciences, \\ Northwestern University, Evanston, Illinois 60208
}

Delays in synaptic and neuronal development in the cortex are key hallmarks of fragile X syndrome, a prevalent neurodevelopmental disorder that causes intellectual disability and sensory deficits and is the most common known cause of autism. Previous studies have demonstrated that the normal progression of plasticity and synaptic refinement during the critical period is altered in the cortex of fragile $\mathrm{X}$ mice. Although the disruptions in excitatory synapses are well documented in fragile $\mathrm{X}$, there is less known about inhibitory neurotransmission during the critical period. GABAergic transmission plays a crucial trophic role in cortical development through its early depolarizing action. At the end of cortical critical period, response properties of GABA transform into their mature hyperpolarizing type due to developmental changes in intracellular chloride homeostasis. We found that the timing of the switch from depolarizing to hyperpolarizing GABA is delayed in the cortex of fragile $\mathrm{X}$ mice and there is a concurrent alteration in the expression of the neuronal chloride cotransporter NKCC1 that promotes the accumulation of intracellular chloride. Disruption of the trophic effects of GABA during cortical development could contribute to the altered trajectory of synaptic maturation in fragile X syndrome.

\section{Introduction}

Fragile X syndrome results from the loss of the fragile X mental retardation protein (FMRP; Verkerk et al., 1991), a polyribosomeassociated RNA-binding protein that regulates the translation of a large number of messenger RNAs, particularly those that encode synaptic proteins (Darnell et al., 2011). Altered trajectories for the development and stability of synaptic connections (Bureau et al., 2008; Cruz-Martín et al., 2010; Testa-Silva et al., 2012) and shifts in the time window for synaptic plasticity have been observed in the cortex of the mouse model of fragile X syndrome (Fmr1 ko; Harlow et al., 2010). However, in many cases, the underlying mechanisms of these alterations remain unknown. One possibility is that disrupted signaling by the neurotransmitter GABA has a strong influence on cortical neuronal development. Although there are multiple lines of evidence demonstrating that GABAergic synaptic transmission and the expression of $\mathrm{GABA}_{\mathrm{A}}$ receptors $\left(\mathrm{GABA}_{\mathrm{A}} \mathrm{Rs}\right.$ ) are perturbed in fragile $\mathrm{X}$ (Paluszkiewicz et al., 2011a) and other neurodevelopmental disorders (Coghlan et al., 2012), this has not been linked to synaptic or neuronal development. During early development, GABA plays a powerful trophic role in the cortex (Represa and Ben-Ari, 2005). $\mathrm{GABA}_{\mathrm{A}} \mathrm{R}$ -

Received Oct. 17, 2013; revised Nov. 19, 2013; accepted Nov. 24, 2013.

Author contributions: Q.H., T.N., J.X., and A.C. designed research; Q.H., T.N., and J.X. performed research; Q.H., T.N., J.X., and A.C. analyzed data; Q.H., T.N., J.X., and A.C. wrote the paper.

This work was supported by the Simons Foundation Autism Research Initiative (SFARI Explorer Award to A.C.), FRAXA (postdoctoral fellowship to Q.H.), the Japan Society for the Promotion of Science Strategic Young Researcher Overseas Visits Program for Accelerating Brain Circulation (to T.N.), and the Nakayama Foundation (fellowship to T.N.).

Correspondence should be addressed to Anis Contractor, Department of Physiology, Northwestern University Feinberg School of Medicine, 303 E. Chicago Ave, Chicago, II 60611. E-mail: a-contractor@northwestern.edu.

DOI:10.1523/JNEUROSCI.4447-13.2014

Copyright $\odot 2014$ the authors $\quad 0270-6474 / 14 / 340446-05 \$ 15.00 / 0$ mediated responses depolarize neurons, increasing their excitability and triggering spiking and $\mathrm{Ca}^{2+}$ entry into neurons, which can activate a number of signaling cascades that affect cell migration, proliferation, dendritic development, and synaptogenesis (Cellot and Cherubini, 2013). This early excitatory depolarizing effect of GABA results from the coordinated expression of neuronal chloride transporters that regulate chloride homeostasis. The $\mathrm{Na}^{+}-\mathrm{K}^{+}-\mathrm{Cl}^{-}$cotransporter (NKCC1) is expressed at high levels early after birth and transports $\mathrm{Cl}^{-}$into neurons; during later development, the expression of the $\mathrm{K}^{+}-\mathrm{Cl}^{-}$cotransporter (KCC2) is elevated, which extrudes $\mathrm{Cl}^{-}$from neurons. Therefore, the relative ratio of the expression of these two neuronal transporters determines the intracellular $\mathrm{Cl}^{-}$concentration $\left[\mathrm{Cl}^{-}\right]_{\text {INT }}$ and the polarity of $\mathrm{GABA}_{\mathrm{A}} \mathrm{R}$ responses: depolarizing when $\left[\mathrm{Cl}^{-}\right]_{\text {INT }}$ is high at birth and hyperpolarizing in the more mature CNS when $\left[\mathrm{Cl}^{-}\right]_{\text {INT }}$ is lower. Alterations in the timing of the polarity switch may disrupt the normal trophic function of GABA and contribute to the delayed maturation of glutamatergic synapses in the cortex of Fmrl ko mice. Here, we found that the normal progression of the chloride reversal potential $\left(E_{\mathrm{Cl}-}\right)$ to more hyperpolarized potentials during the first and second postnatal week was delayed in cortical neurons of Fmr1 ko mice. The maintenance of a relatively depolarized $E_{\mathrm{Cl}}$ was correlated with increased expression of NKCC1 at the end of the critical period. These results represent a novel finding of a disruption that will affect the change in GABA transmission polarity during early development, which in turn could affect neuronal development in the cortex of Fmr1 ko mice.

\section{Materials and Methods}

Electrophysiology. Paracoronal sections containing the somatosensory cortex $(400 \mu \mathrm{m})$ were prepared as described previously from male post- 


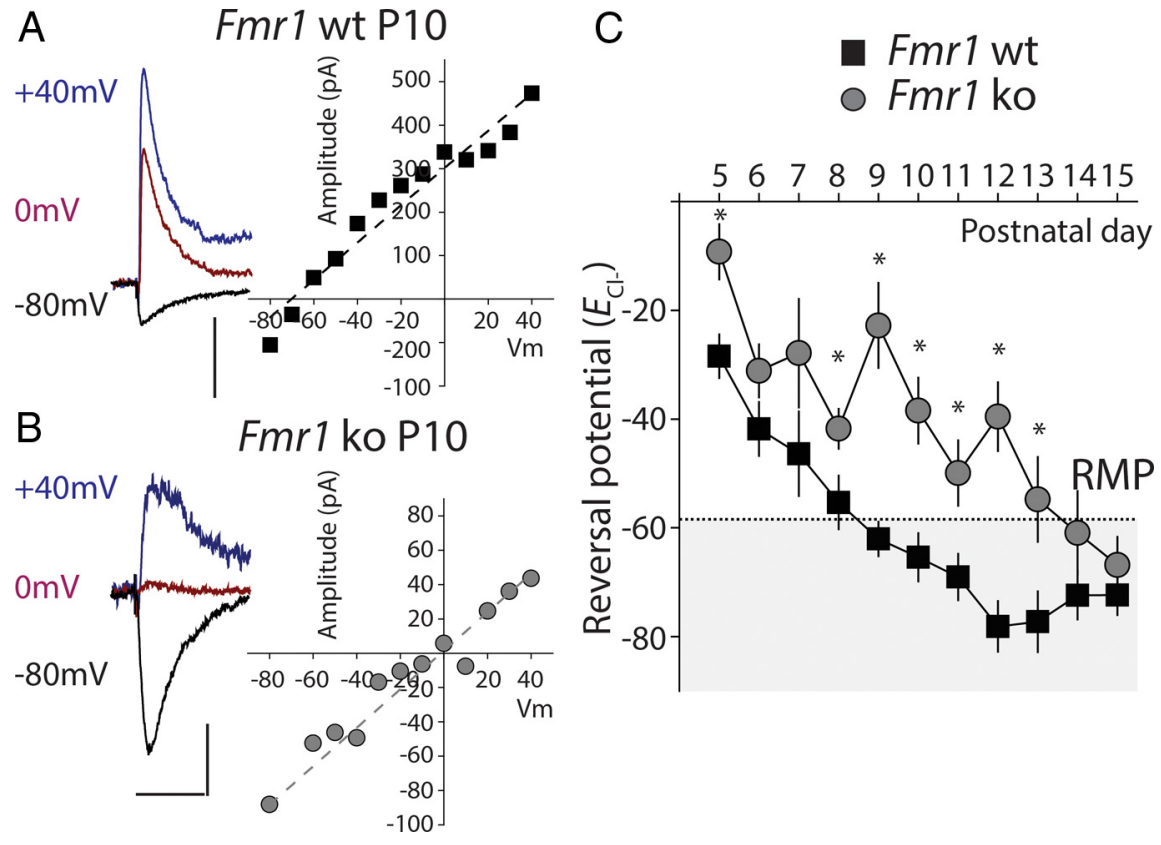

Figure 1. $E_{\mathrm{Cl}}$ remains depolarized in Fmr1 ko mice during cortical development. $\boldsymbol{A}$, Representative example of a perforated patch-clamp recording from a layer IV neuron in the somatosensory cortex of a P10 Fmr1 wt mouse. Recordings were made at

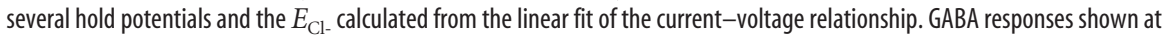
$-80,0$, and $+40 \mathrm{mV}$ were evoked by extracellular stimulation in the presence of glutamate blockers D-APV (50 $\mu \mathrm{M})$ and CNQX (10 $\mu \mathrm{M})$. Calibration for current traces: $50 \mathrm{~ms}, 200 \mathrm{pA}$. B, Representative recording from Fmr 1 ko at $\mathrm{P} 10$ and current-voltage relationship of GABA-mediated currents. $E_{\mathrm{Cl} \text { - }}$ is significantly more depolarized at this age in recordings from Fmr 1 ko mice. Calibration for current traces: $50 \mathrm{~ms}, 50 \mathrm{pA}$. C, Grouped data from all recordings. The average $E_{\mathrm{Cl}}$ calculated from each individual recording is plotted against the age of the mouse (postnatal day). The RMP measured at P10 is denoted by the dashed line and shaded area represents points at which GABA would have a mature hyperpolarizing response. ${ }^{*} p<0.05$ (P5: wt, $n=13 ;$ ko $n=4$. P6: wt, $n=$ $6 ; \mathrm{ko}, n=11$. P7: wt, $n=6 ; \mathrm{ko}, n=4$. P8: wt, $n=10: \mathrm{k0}, n=8$. P9: wt, $n=8 ; \mathrm{ko}, n=11 . \mathrm{P} 10: \mathrm{wt}, n=8 ; \mathrm{ko}, n=5$. P11: wt, $n=16 ; \mathrm{ko}, n=14$. P12: wt, $n=17 ; \mathrm{ko}, n=6$. P13: wt, $n=12$ : ko, $n=5$. P14: wt, $n=11$ : ko, $n=10$. P15: wt, $n=12 ; \mathrm{k}$, $n=7)$.

natal day 5 (P5) to P15 Fmr1-knock-out (ko) mice $\left(F m r 1^{-/ y}\right)$ and their male wild-type $\left(F m r 1^{+/ y}\right)$ littermates (Harlow et al., 2010). Mice were on a congenic C57BL/6 inbred background strain. Experiments were performed with the experimenter blind to the genotype of the animal, followed by post hoc genotyping using DNA from tail biopsies. Mice were anesthetized with isoflurane, decapitated, and the brain rapidly removed under ice-cold, oxygenated, sucrose-slicing ACSF containing the following (in mM): $85 \mathrm{NaCl}, 2.5 \mathrm{KCl}, 1.2 \mathrm{NaH}_{2} \mathrm{PO}_{4}, 25 \mathrm{NaHCO}$, 25 glucose, 75 sucrose, $0.5 \mathrm{CaCl}_{2}$, and $4 \mathrm{MgCl}_{2}$ equilibrated with $95 \% \mathrm{O}_{2} / 5 \% \mathrm{CO}_{2}$ and supplemented with the glutamate antagonists $100 \mu \mathrm{M}$ kynurenate and 10 $\mu \mathrm{M}$ APV. Slices were incubated at $28^{\circ} \mathrm{C}$ for $30 \mathrm{~min}$ while slowly exchanging the sucrose ACSF in the incubation chamber for oxygenated sodium ACSF solution containing the following (in $\mathrm{mM}$ ): $125 \mathrm{NaCl}, 2.4 \mathrm{KCl}, 1.2$ $\mathrm{NaH}_{2} \mathrm{PO}_{4}, 25 \mathrm{NaHCO}_{3}, 25$ glucose, $1 \mathrm{CaCl} 2$, and $2 \mathrm{MgCl} 2$. After a recovery period at least $1 \mathrm{~h}$, slices were transferred to a recording chamber, where they were continuously perfused with oxygenated sodium ACSF containing $2 \mathrm{mM} \mathrm{CaCl}_{2}$ and $1 \mathrm{mM} \mathrm{MgCl}_{2}$ and visualized under differential interference contrast. Perforated patch-clamp recordings were made from layer IV neurons in the somatosensory cortex at elevated temperature $\left(32^{\circ} \mathrm{C}\right)$ using a Multiclamp $700 \mathrm{~B}$ patch-clamp amplifier (Molecular Devices). Spiny stellate cells are the most abundant neurons in layer IV (Feldmeyer et al., 1999) and were identified by their dense distribution in the walls of the barrel, their regular soma size $(\sim 10 \mu \mathrm{m})$, and their morphology lacking a prominent apical dendrite (Daw et al., 2007).

Glass recording electrodes had resistances of 5-7 M $\Omega$ when filled with $\mathrm{KCl}$ solution containing $150 \mathrm{~mm} \mathrm{KCl}$ and $10 \mathrm{~mm}$ HEPES pH adjusted to 7.2 with Tris-OH. The pipette tip was filled with gramicidin-free $\mathrm{KCl}$ solution and then backfilled with solution containing gramicidin (100 $\mu \mathrm{g} / \mathrm{ml}$; Ebihara et al., 1995). GABAergic currents were evoked in the presence of $50 \mu \mathrm{M}$ D-APV and $10 \mu \mathrm{M}$ CNQX using a glass monopolar extracellular stimulating electrode filled with ACSF positioned at the border of layer IV and $\mathrm{V}$ and recorded at holding potential between $-80 \mathrm{mV}$ and $+40 \mathrm{mV}$. The reversal potential of GABAergic currents was calculated from the intersection of the current-voltage relationship with the $x$-axis.

Western blots. Male pups of Fmr1 ko and Fmrl wild-type (wt) genotypes were euthanized at P5, P10, and P15 and coronal slices were sectioned from $0.5 \mathrm{~mm}$ to $-2.0 \mathrm{~mm}$ in relation to bregma in ice-cold ACSF. The somatosensory barrel cortex subfield tissue was carefully dissected out with scalpel blades. Membrane protein was homogenized and samples were subjected to further extraction using a ProteoExtract Subcellular Proteome Extraction Kit (Calbiochem, EMD Millipore). The samples were subsequently separated on a 4-15\% Mini-PROTEAN TGX Precast gel using electrophoresis and transferred to polyvinylidene fluoride transfer membrane. The blots were probed with T4 monoclonal $\alpha$-NKCC1 antibody (1:1000; Developmental Studies Hybridoma Bank, University of Iowa) and a mouse $\alpha$-KCC2 antibody (1:500, Neuromab; University of California-Davis), and $\alpha$ - $\beta$-tubulin III antibody (1:12000; SigmaAldrich). A standard enhanced chemiluminescence substrate (EMD Millipore) was used for detection of protein bands, and quantification of band density was performed using ImageLab software. The amounts of NKCC1 and KCC2 proteins were quantified by normalizing the optical density of the correct molecular weight band to that of $\beta$-tubulin on the same membrane.

RNA purification and real-time $q P C R$. Tissue from cortex was isolated as described above from Fmr1 ko and Fmr1 wt mice at P5, P10, and P15. Total RNA was extracted using TRIzol reagent (Ambion) and used (20 ng per sample) for the synthesis of cDNA using SuperScript III RT Reverse Transcriptase from Superscript VILO Mastermix (Invitrogen). Real-time RT-PCR was performed using the 7900HT Fast Real-Time PCR system. Primers and probes for expression analysis of the different transcripts were designed and produced using TaqMan assays (Life Technologies).

Probes for NKCC1, KCC2, and the reference gene GAPDH were obtained from Life Technologies and were as follows: NKCC1: Slc12a2Mm01265951_m1; KCC2: Slc12a5-Mm00803929_m1; GAPDH: Mm99999915_g1. All measurements were made in triplicate and relative quantification was performed using the comparative threshold (CT) after determining the values of CT for the reference gene GAPDH and the target gene KCC2 or NKCC1 in each sample. The $R_{\mathrm{q}}$ ratio of target/ reference gene was used to make comparisons between Fmrl wt and Fmrl ko samples. $R_{\mathrm{q}}$ was calculated using the following formula: $R_{\mathrm{q}}=$ $2^{-\Delta C_{T}}$, where $\Delta C_{\mathrm{T}} \stackrel{\text { q }}{=} \mathrm{C}_{\mathrm{T}}$ target gene $-\mathrm{C}_{\mathrm{T}}$ reference gene.

Statistical analyses were conducted with GraphPad Prism software. Post hoc Bonferroni pairwise comparisons were performed when significant effects were found by two-way ANOVA. Differences between two means were assessed with $t$ tests. Data are presented as mean \pm SEM. Differences were considered significant when $p<0.05$.

\section{Results}

Based on the known trophic effects of depolarizing GABA and the altered development of synapses in the cortex of fragile $\mathrm{X}$ mice during critical period development (Cruz-Martín et al., 2010; Harlow et al., 2010), we wanted to determine whether the timing of the GABA polarity switch in cortical neurons was disrupted in the mouse model of fragile $\mathrm{X}$ syndrome. To do this, we measured 

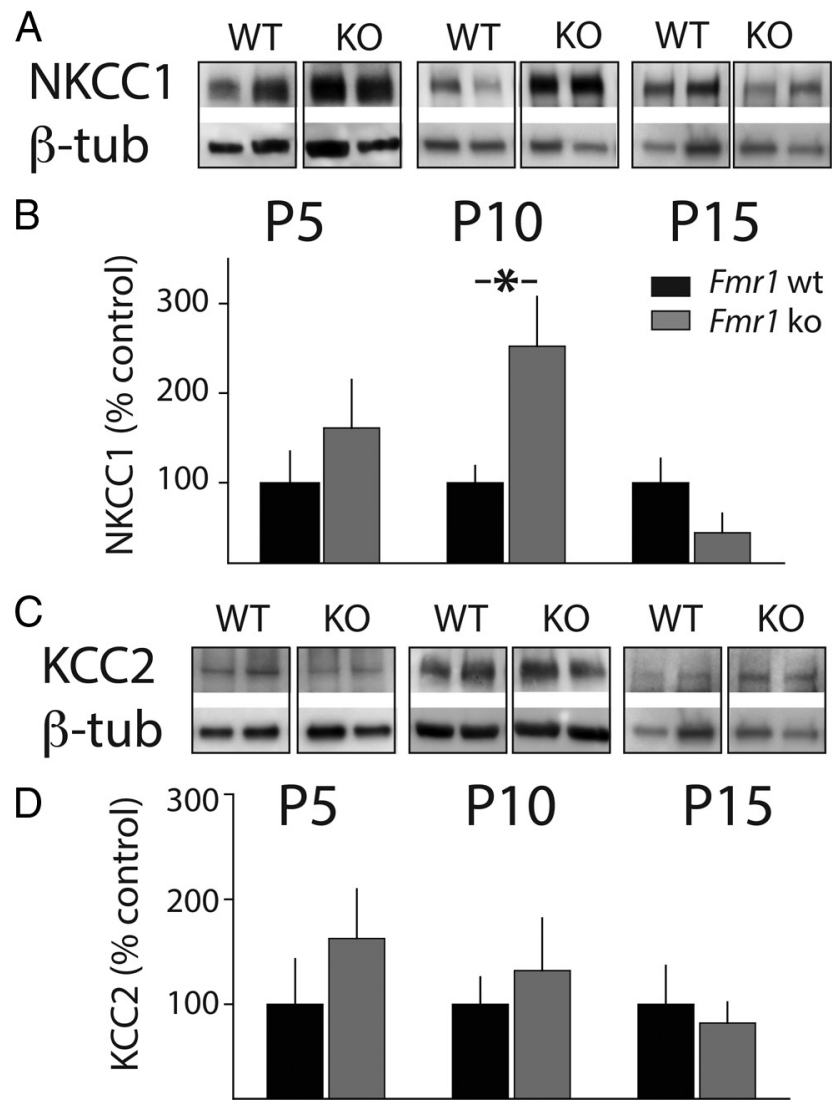

Figure 2. Expression of the juvenile chloride cotransporter NKCC1. $\boldsymbol{A}$, The expression of NKCC 1 is elevated in the cortex of $F m r 1$ ko mice at the close of the critical period. Representative gel run with cortical homogenates from $F m r 1$ wt and $F m r 1$ ko mice and probed with anti-NKCC 1 and anti- $\beta$-tubulin ( $\beta$-tub). Western blots were used to measure NKCC1 protein levels at three developmental time points: $\mathrm{P} 5, \mathrm{P} 10$, and P15. $\boldsymbol{B}$, Grouped data from all experiments. The average intensity of NKCC1 was normalized to $\beta$-tubulin in Fmr1 wt and Fmr 1 ko in each sample at each age (P5: wt, $n=8 ; \mathrm{ko}, n=8$. P10: wt, $n=11 ; \mathrm{ko}, n=$ 11. P15: wt, $n=8 ; \mathrm{ko}, n=7$ ). A significant elevation of NKCC1 protein levels was observed at P10 in samples from the Fmr 1 ko mice. ${ }^{*} p<0.05$. C, Representative Western blots for cortical homogenates probed with anti-KCC2 antibodies from Fmr1 wt and Fmr1 ko mice at P5, P10, and P15. D, Grouped data for all KCC2 Western blots (P5: wt, $n=8 ; \mathrm{k}$, $n=8$. P10: wt, $n=11 ; \mathrm{k} 0, n=11 ; \mathrm{P} 15: \mathrm{wt}, n=8 ; \mathrm{k} 0, n=7)$. No difference in relative protein levels was observed at any age between the two genotypes $(p>0.05)$. All values are means \pm SEM.

the potential at which $\mathrm{GABA}_{\mathrm{A}} \mathrm{R}$ responses reverse $\left(E_{\mathrm{Cl}}\right)$ in layer IV spiny stellate neurons in the somatosensory cortex. Perforated patch recording were made from stellate neurons in paracoronal slices from $F m r 1^{-/ y}\left(F m r 1\right.$ ko) and littermate Fmr1 ${ }^{+/ y}$ controls (Fmr1 wt). GABA-mediated responses were elicited by intracortical stimulation and isolated by the application of antagonist of glutamate receptors ( $50 \mu \mathrm{M}$ D-APV and $10 \mu \mathrm{M}$ CNQX). Responses were recorded while voltage clamping the membrane at various holding potentials between $-80 \mathrm{mV}$ and +40 $\mathrm{mV}$ (Fig. $1 A, B$ ). The measured current-voltage relationship was used to determine $E_{\mathrm{Cl}}$. Recordings were made at each postnatal day starting at P5 up to P15. We found that even at the earliest time points during the first postnatal week, there was a small difference in the $E_{\mathrm{Cl}}$, although it was not significant at every postnatal day (P6 Fmrl wt, $E_{\mathrm{Cl}-}: 42.8 \pm 5.0 \mathrm{mV}$, $n=6$; Fmrl ko, $E_{\mathrm{Cl}}:-31.4 \pm 4.9 \mathrm{mV}, n=11, p>0.05$; Fig. $1 C) . E_{\mathrm{Cl}}$ became progressively more hyperpolarized at each successive day during the second postnatal week in both genotypes. However, in Fmrl ko animals, $E_{\mathrm{Cl}}$ stayed relatively de-
A

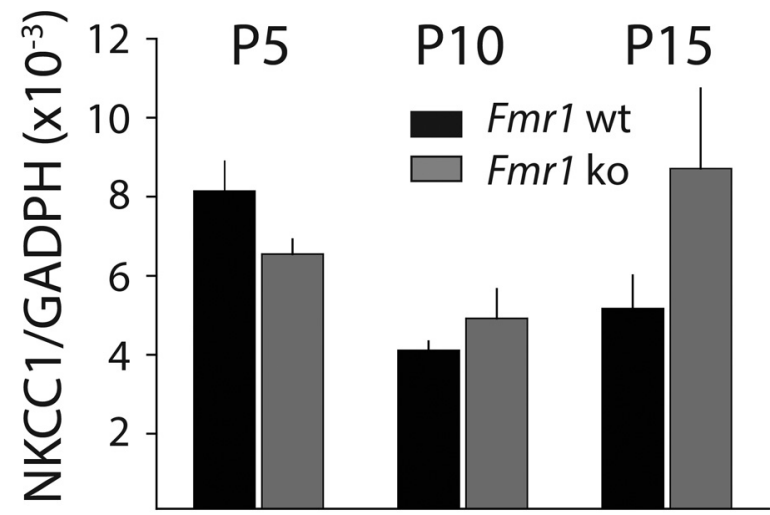

$\mathrm{B}$

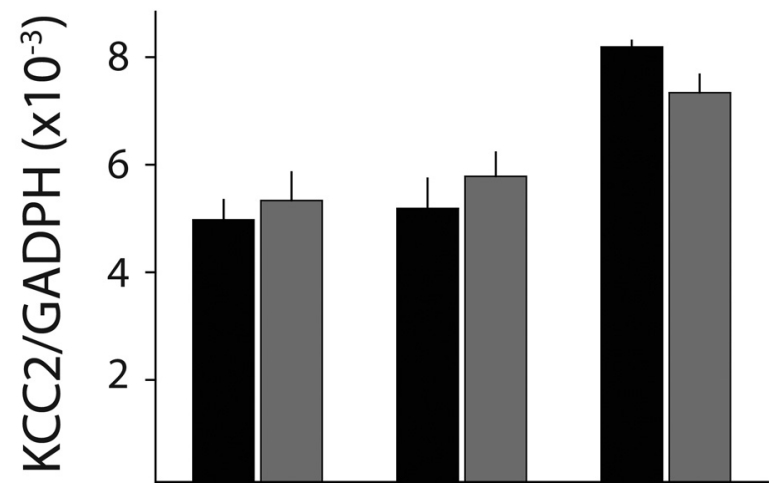

Figure 3. Chloride cotransporter transcript expression is not altered in cortex of Fmr $1 \mathrm{ko}$ mice. $\boldsymbol{A}$, Relative transcript abundance of NKCC1 in cortex of Fmr 1 wt and Fmr 1 ko at P5, P10, and P15. B, Relative RNA expression of KCC2 in Fmr 1 wt and Fmr 1 ko at P5, P10, and P15. $R_{\mathrm{q}}$ was calculated as the ratio of the target gene to GAPDH as the reference gene ( $p>0.05$ for all age groups for both NKCC1 and KCC2).

polarized so that at the closure of critical period in layer IV at P10 (Daw et al., 2007), when GABA has a mature hyperpolarizing effect, $E_{\mathrm{Cl}}$ - was more depolarized than the resting membrane potential (RMP) and was significantly different from $E_{\mathrm{Cl}-}$ in Fmr1 wt (Fmr1 ko, P10: $E_{\mathrm{Cl}-}=-38.4 \pm 6.1 \mathrm{mV}, n=5$; Fmr1 ko, P10, $E_{\mathrm{Cl}-}=-65.4 \pm 4.4 \mathrm{mV}, n=8 p<0.05$; Fig. $1 C$ ). We also measured the RMP of layer IV neurons, but found no difference between the genotypes (Fmr1 ko, P10, $V_{\mathrm{m}}:-60.0 \pm$ $1.0 \mathrm{mV}, n=19$; Fmrl wt, P10, $V_{\mathrm{m}}:-58.7 \pm 1.5 \mathrm{mV}, n=26$, $p>0.05)$. Therefore, at this important postnatal milestone at the close of the critical period, GABA elicits depolarizing responses in Fmr1 ko animals, but elicits a mature hyperpolarizing current in Fmr1 wt neurons. By the end of the second postnatal week, $E_{\mathrm{Cl}}$ - was more hyperpolarized than the RMP in both genotypes and no difference was observed between recordings from Fmr1 ko and Fmr1 wt mice (Fmr1 ko, P15, $E_{\mathrm{Cl}}$ : $-66.8 \pm 5.1 \mathrm{mV}, n=7 ;$ Fmrl wt, P15, $E_{\mathrm{Cl}}=-72.4 \pm 4.7 \mathrm{mV}$, $n=12, p>0.05$; Fig. $1 C$ ).

$E_{\mathrm{Cl}-}$ is determined by the regulated expression of $\mathrm{NKCC} 1$ and KCC2 during development. To address whether altered protein levels of these two chloride cotransporters might contribute to the disruption in the polarity switch for GABA, we microdissected tissue from somatosensory cortex and immunoblotted for NKCC1 and KCC2 at P5, P10, and P15. At P5 and $\mathrm{P} 15$, there was no significant difference in the relative amount of NKCC1 (Fig. 2A,B). However, at P10, there was a significant elevation in NKCC1 expression in samples from 
Fmr1 ko animals relative to those from Fmr1 wt $(252 \pm 55.2 \%$ $n=8, p<0.05$; Fig. $2 A, B)$. The relative expression levels of KCC2 were not different between the two genotypes at any of the postnatal days tested (Fig. 2C,D). An elevation in NKCC1 and no alteration in KCC2 protein levels in P10 Fmr1 ko mice changes the relative ratio of these two important chloride cotransporters and suggests that this could account for the altered $E_{\mathrm{Cl}}$ - we observed.

To determine whether the altered protein levels of NKCC1 are accompanied by changes in the level of transcripts, we performed qPCR on samples from Fmrl wt and Fmrl ko mice at the same time points ( $\mathrm{P} 5, \mathrm{P} 10$ and $\mathrm{P} 15)$. Tissue samples were again microdissected from the somatosensory cortex and the purified RNA underwent reverse transcription. Using probes for both the KCC2 and NKCC1 genes, we found no difference in the relative expression levels of either of these transcripts in Fmrl ko mice in samples taken from all three developmental time points (Fig. $3 A, B)$. Together, our results demonstrate a potentially important cellular developmental disruption in chloride homeostasis that could have pleiotropic effects on synaptic development in the cortex of Fmr1 ko mice.

\section{Discussion}

Network hyperexcitability in the cortex has been well documented in Fmr1 ko mice (Gibson et al., 2008; Goncalves et al., 2013) and is proposed to underlie the increased propensity for seizures, hyperarousal, and hypersensitivity to sensory stimuli seen in fragile $\mathrm{X}$ syndrome. Several studies have demonstrated both molecular and functional disruption in GABA signaling (El Idrissi et al., 2005; D'Hulst et al., 2006; Gantois et al., 2006; Paluszkiewicz et al., 2011b). However, until now, there has not been an examination of GABA signaling in Fmrl ko mice during early development, when it has a strong trophic role on neuronal development (Represa and Ben-Ari, 2005). Multiple lines of evidence have demonstrated that there are functional and structural changes in synapses during the early postnatal period in Fmr1 ko mice. Our finding that there is a delay in the timing of the GABA polarity switch in principal neurons of the cortex may provide one explanation for the observed changes in synaptic development. We observed an increase in protein expression of the juvenile chloride cotransporter whereas mRNA was not affected. The chloride cotransporter mRNAs are not known Fmrp targets and it is possible that upregulation of NKCC1 is due to a pleiotropic effect in the knock-out. The actual mechanisms that control the developmental expression of the chloride cotransporters are not known. However, $G_{A B A} R$ signaling itself can affect the polarity switch (Ganguly et al., 2001). Because there are documented changes in inhibitory neural circuitry and $\mathrm{GABA}_{\mathrm{A}} \mathrm{R}$ expression in Fmr1 ko mice (Paluszkiewicz et al., 2011a), it is possible that these contribute to the disrupted chloride homeostasis that we have discovered. Changes in inhibitory transmission have been observed in several neurodevelopmental disorders, particularly those that are linked to autism such as fragile $\mathrm{X}$ syndrome. A recent clinical trial with bumetanide, a commonly used diuretic that inhibits NKCC1 function, demonstrated improvement in clinical scores for autism patients, suggesting that NKCC1 function may be upregulated in autism and may be a causal factor in some of the behavioral disruptions associated with autism (Lemonnier et al., 2012). In addition, a recent study that analyzed protein concentration in the CSF of Rett syndrome patients demonstrated an upregulation in the ratio of
NKCC1 to KCC2, further suggesting that alterations in chloride transporters might be a general finding in neurodevelopmental disorders linked with autism (Duarte et al., 2013). Our results are the first to describe the maintenance of a depolarized $E_{\mathrm{Cl}}$ in the cortex to later developmental time points and a change in the relative expression of the chloride cotransporters in the cortex of the mouse model of fragile X syndrome. It is possible that a delay in the polarity switch in GABA responses will have effects on the development of synaptic connections during the cortical critical period. Inhibiting chloride transport into neurons may thus correct some of the alteration in the development of synapses that underlie the cognitive and sensory problems experienced by individuals with fragile $\mathrm{X}$ syndrome.

\section{References}

Bureau I, Shepherd GM, Svoboda K (2008) Circuit and plasticity defects in the developing somatosensory cortex of FMR1 knock-out mice. J Neurosci 28:5178-5188. CrossRef Medline

Cellot G, Cherubini E (2013) Functional role of ambient GABA in refining neuronal circuits early in postnatal development. Front Neural Circuits 7:136. CrossRef Medline

Coghlan S, Horder J, Inkster B, Mendez MA, Murphy DG, Nutt DJ (2012) GABA system dysfunction in autism and related disorders: from synapse to symptoms. Neurosci Biobehav Rev 36:2044-2055. CrossRef Medline

Cruz-Martín A, Crespo M, Portera-Cailliau C (2010) Delayed stabilization of dendritic spines in fragile X mice. J Neurosci 30:7793-7803. CrossRef Medline

Darnell JC, Van Driesche SJ, Zhang C, Hung KY, Mele A, Fraser CE, Stone EF, Chen C, Fak JJ, Chi SW, Licatalosi DD, Richter JD, Darnell RB (2011) FMRP stalls ribosomal translocation on mRNAs linked to synaptic function and autism. Cell 146:247-261. CrossRef Medline

Daw MI, Ashby MC, Isaac JT (2007) Coordinated developmental recruitment of latent fast spiking interneurons in layer IV barrel cortex. Nat Neurosci 10:453-461. CrossRef Medline

D’Hulst C, De Geest N, Reeve SP, Van Dam D, De Deyn PP, Hassan BA, Kooy RF (2006) Decreased expression of the GABAA receptor in fragile $\mathrm{X}$ syndrome. Brain Res 1121:238-245. CrossRef Medline

Duarte ST, Armstrong J, Roche A, Ortez C, Perez A, O’Callaghan Mdel M, Pereira A, Sanmartí F, Ormazábal A, Artuch R, Pineda M, García-Cazorla A (2013) Abnormal expression of cerebrospinal fluid cation chloride cotransporters in patients with Rett syndrome. PLoS One 8:e68851. CrossRef Medline

Ebihara S, Shirato K, Harata N, Akaike N (1995) Gramicidin-perforated patch recording: GABA response in mammalian neurones with intact intracellular chloride. J Physiol 484:77-86. Medline

El Idrissi A, Ding XH, Scalia J, Trenkner E, Brown WT, Dobkin C (2005) Decreased GABAA receptor expression in the seizure-prone fragile $\mathrm{X}$ mouse. Neurosci Lett 377:141-146. CrossRef Medline

Feldmeyer D, Egger V, Lubke J, Sakmann B (1999) Reliable synaptic connections between pairs of excitatory layer 4 neurones within a single 'barrel' of developing rat somatosensory cortex. J Physiol 521:169-190. CrossRef Medline

Ganguly K, Schinder AF, Wong ST, Poo M (2001) GABA itself promotes the developmental switch of neuronal GABAergic responses from excitation to inhibition. Cell 105:521-532. CrossRef Medline

Gantois I, Vandesompele J, Speleman F, Reyniers E, D’Hooge R, Severijnen LA, Willemsen R, Tassone F, Kooy RF (2006) Expression profiling suggests underexpression of the GABAA receptor subunit $\delta$ in the fragile $\mathrm{X}$ knockout mouse model. Neurobiol Dis 21:346-357. CrossRef Medline

Gibson JR, Bartley AF, Hays SA, Huber KM (2008) Imbalance of Neocortical Excitation and Inhibition and Altered UP States Reflect Network Hyperexcitability in the Mouse Model of Fragile X Syndrome. J Neurophysiol 100: 2615-2626. CrossRef Medline

Gonçalves JT, Anstey JE, Golshani P, Portera-Cailliau C (2013) Circuit level defects in the developing neocortex of Fragile X mice. Nat Neurosci 16: 903-909. CrossRef Medline

Harlow EG, Till SM, Russell TA, Wijetunge LS, Kind P, Contractor A (2010) Critical period plasticity is disrupted in the barrel cortex of FMR1 knockout mice. Neuron 65:385-398. CrossRef Medline 
Lemonnier E, Degrez C, Phelep M, Tyzio R, Josse F, Grandgeorge M, Hadjikhani N, Ben-Ari Y (2012) A randomised controlled trial of bumetanide in the treatment of autism in children. Transl Psychiatry 2:e202. CrossRef Medline

Paluszkiewicz SM, Martin BS, Huntsman MM (2011a) Fragile X syndrome: the GABAergic system and circuit dysfunction. Dev Neurosci 33:349364. CrossRef Medline

Paluszkiewicz SM, Olmos-Serrano JL, Corbin JG, Huntsman MM (2011b) Impaired inhibitory control of cortical synchronization in fragile X syndrome. J Neurophysiol 106:2264-2272. CrossRef Medline

Represa A, Ben-Ari Y (2005) Trophic actions of GABA on neuronal development. Trends Neurosci 28:278-283. CrossRef Medline
Testa-Silva G, Loebel A, Giugliano M, de Kock CP, Mansvelder HD, Meredith RM (2012) Hyperconnectivity and slow synapses during early development of medial prefrontal cortex in a mouse model for mental retardation and autism. Cereb Cortex 22:1333-1342. CrossRef Medline

Verkerk AJ, Pieretti M, Sutcliffe JS, Fu YH, Kuhl DP, Pizzuti A, Reiner O, Richards S, Victoria MF, Zhang FP, Eussen BE, van Ommen G-JB, Blonden LAJ, Riggins GJ, Chastain JL, Kunst CB, Galjaard H, Caskey CT, Nelson DL, Oostraa BA, et al. (1991) Identification of a gene (FMR-1) containing a CGG repeat coincident with a breakpoint cluster region exhibiting length variation in fragile X syndrome. Cell 65:905-914. CrossRef Medline 